\title{
Just Rewards? \\ Local Politics and Public Resource Allocation in South India*
}

\author{
Timothy Besley \\ LSE and CIFAR
}

\author{
Rohini Pande \\ Harvard University
}

\author{
Vijayendra Rao \\ World Bank
}

DEDPS 49

October 2007
The Suntory Centre

Suntory and Toyota International Centres for Economics and Related Disciplines

London School of Economics and Political Science Houghton Street

London WC2A 2AE

\footnotetext{
* We thank Lupin Rahman, Radu Ban, Siddharth Sharma and Jillian Waid for research assistance, and IMRB staff for conducting the survey. We are grateful to Penny Goldberg, Dominic Leggett, Chris Udry and seminar audiences at Berkeley, Georgetown, NBER, Oxford, Yale and at a meeting of the CIFAR Institutions, Organizations and Growth program for comments, and to the World Bank's Research Committee and the South Asia Rural Development Unit for financial support. The opinions in the paper are those of the authors and do not necessarily reflect the points of view of the World Bank or its member countries.
} 


\begin{abstract}
This paper uses data on elected village councils in South India to examine the political economy of public resource allocation. We find that the pattern of policy-making reflects politicians' self-interest. Elected councillors benefit from improved personal access to public resources. In addition, the head councillor's group identity and residence influences public resource allocation. While electoral incentives do not eliminate politician opportunism, voters appear able to use their electoral clout to gain greater access to public resources.
\end{abstract}

Key words: decentralization, India, Panchayat.

JEL codes: $\mathrm{H} 76, \mathrm{H} 11, \mathrm{O} 12$ 


\section{Development Economics Discussion Paper Series}

This series is published by the Economic Organisation and Public Policy Programme (EOPP) located within the Suntory and Toyota International Centres for Economics and Related Disciplines (STICERD) at the London School of Economics and Political Science. The programme was established in October 1998 as a successor to the Development Economics Research Programme. The work of the programme is mainly in the fields of development economics, public economics and political economy. It is directed by Tim Besley, Oriana Bandiera, Robin Burgess, Maitreesh Ghatak and Andrea Prat. Further details about the programme and its work can be viewed on our web site at http://sticerd.lse.ac.uk/research/eopp.

Our Discussion Paper series is available free of charge. To subscribe to DEDPS, please contact Leila Alberici on:

$\begin{array}{ll}\text { Telephone: } & \text { UK+20 } 79556674 \\ \text { Fax: } & \text { UK+20 7955 6951 } \\ \text { Email: } & \text { l.alberici @lse.ac.uk } \\ \text { Web site: } & \text { http://sticerd.lse.ac.uk/dedps }\end{array}$

Tim Besley

Oriana Bandiera

Robin Burgess

Maitreesh Ghatak

Andrea Prat

(C) The authors. All rights reserved. Short sections of text, not to exceed two paragraphs, may be quoted without explicit permission provided that full credit, including (C) notice, is given to the source. 


\section{Introduction}

This paper uses data on elected village councils in South India to examine the political economy of public resource allocation. We focus on four facets of the political process - self interest, group interest, institutional rules and policy commitment. Elected councillors benefit from improved personal access to public resources. While electoral incentives do not eliminate politician opportunism, voters are able to use their electoral clout to gain greater access to public resources. Specifically, the head village councillor is more likely to belong to the largest village in the council which then benefits from greater public good activism. Finally, socially and economically disadvantaged households in a village enjoy improved access to public resources when the head village councillor belongs to their group.

In 1993, a constitutional amendment instituted village-level self government, or Gram Panchayats (GP), in rural India. A typical GP comprises of several villages, with policy-making delegated to elected village councillors. While Indian states vary in whether the head councillor (Pradhan) is elected directly by villagers or indirectly by the village councillors, the electoral institution underlying all GP elections remains plurality rule.

In 2002, we collected village level and household survey data in roughly 500 South Indian villages. ${ }^{1}$ We use these data to examine who gains access to political authority and how they use that authority to affect public resource targeting across villages and across households within villages.

We have a precise measure of personal political opportunism - whether a politician's household is allocated a Below Poverty Line (BPL) card. Instituted in 1997, this state-subsidized program entitles households to buy food below market prices. The GP administration is used to identify beneficiary households based on need. After controlling for the correlates of household disadvantage which predict BPL card allocation, we find that politician households are more likely to be BPL program beneficiaries. Further, BPL card-holding politicians are less likely to allocate BPL cards to socially and economically disadvantaged households, and villagers are more dissatisfied with the performance of these politicians.

We then examine public resource allocation across villages in a GP. The fact that the Pradhan enjoys significant discretionary policy powers suggests that villages

\footnotetext{
${ }^{1}$ Besley, Pande, Rahman and Rao [2004a] and Besley, Pande, Rao [2005] look at various aspects of resource allocation in Panchayats using the data from this study.
} 
within a GP are likely to compete for the Pradhan's chair. We show that a plurality based electoral system provides the largest village in the GP with a significant electoral advantage in capturing the Pradhan's chair. The Pradhan's village, in turn, benefits from greater public good activism. These findings are consistent with the idea that voters are aware of political discretion in policy-making and accordingly use their electoral clout to ensure that resources are directed towards them.

Finally, we return to BPL card allocation to examine the role of group interest. Specifically, we exploit cross-GP variation in whether the position of the Pradhan is reserved for traditionally disadvantaged groups (women and low castes). We find that low caste households are significantly more likely to be allocated BPL cards when the Pradhan shares their group identity.

Our findings impact on several theoretical questions about the political economy of public resource allocation, and about the effects of political decentralization.

The classic analysis of decentralization, beginning with Oates (1972), argues that policy in a decentralized setting will reflect the preferences of the local median voter. ${ }^{2}$ In extremis, this view predicts that voters' policy preferences, not political institutions, determine local policy outcomes. However, we find evidence that a politician's group identity and self-interest also influence public resource allocation. This would suggest that when there are several elected politicians, as is the case in a Gram Panchayat, institutional structure will matter.

There are two broad (theoretical) views about how decision-making will work in such settings. Weingast, Shepsle and Johnsen (1981) emphasize the possibility of a cooperative outcome (universalism) in which there is a relatively equal allocation of public resources across villages. Others, such as Riker (1962) and Baron (1991), have emphasized the incentive for a minimal winning coalition to form comprising a majority of representatives designing policy skewed in favor of the ruling coalition. Our results, which show that the Pradhan's village is favored, are more consistent with the latter view. ${ }^{3}$

Whether the policy choices of elected legislators will reflect the interests of the

\footnotetext{
${ }^{2}$ In line with this view, Faguet (2004) and Foster and Rosenzweig (2001) both argue that decentralization affects whose policy preferences are decisive. Other studies of resource allocation in GPs include Bardhan and Mookherjee (2003), who examine the role of elected village councils, and Chattopadhyay and Duflo (2004) who examine public good allocation in West Bengal villages.

${ }^{3} \mathrm{~A}$ number of contributions have tried to test the empirical relevance of universalism using U.S. local government data. The findings are mixed - see, for example, Baqir (2002), Bradbury and Stephenson (2003) and MacDonald and Sass (2005).
} 
citizens they represent depends, to a large extent, on the extent of policy commitment - a point underlined by the citizen-candidate approach to political competition of Besley and Coate (1997) and Osborne and Slivinski (1996). Our finding that a politician's group identity affects the way that political authority is exercised is consistent with an emerging body of evidence which shows that political reservation for a group can change policy outcomes. ${ }^{4}$

A frequent concern in the literature on decentralization in developing countries is that elites will capture the policy agenda. ${ }^{5}$ In a sense this view also plays down the role of formal political institutions in shaping resource allocation - with policy instead being shaped by pre-existing traditional power structures. While we cannot use our results to rule out a potential role for village elite in local policy-making, they do suggest that it cannot be the whole story since political institutions influence policy outcomes. ${ }^{6}$

Finally, our paper contributes to discussions about political corruption in lowincome countries (Pande 2007). It is notoriously difficult to obtain persuasive measures of corruption (Olken 2006). There is also limited evidence on the extent to which corruption distorts resource allocation in low income settings, and on whether higher levels of corruption reflect different norms in these countries (for some recent evidence on these issues, see Goldstein and Udry (2006) and Fisman and Miguel (2007), respectively). One advantage of our study is that we use a very specific measure of political self-dealing in the form of BPL cards, and only exploit within-village variation in BPL card allocation to examine politician opportunism. We find that political opportunism is accompanied by worse targeting of public resources, and that villagers are significantly less satisfied with self-dealing politicians. ${ }^{7}$ Taken to-

\footnotetext{
${ }^{4}$ Chattopadhyay and Duflo (2004) and Ban and Rao (2007) examine how women's reservation in Panchayats affects spending patterns in West Bengal and South Indian villages, respectively. Pande (2003) analyzes the policy impact of state-wide reservation for Scheduled castes and Scheduled tribes.

${ }^{5}$ See Platteau (2004) for general discussion of elite capture and an interesting West African case study. For broad discussions of the issues concerning decentralization, see Bardhan (2002), Crook and Manor (1998), Triesman (2007).

${ }^{6}$ Our focus on how politician self-interest and group-interest influence local policy-making is closely related to Chattopadhyay, Duflo and Fisher (2006) who examine efficiency and rent-seeking in village governments in Bengal. They find that low caste Pradhans undertake greater policy activism in low caste hamlets. However, they do not find evidence for greater public good activism in the Pradhan village.

${ }^{7}$ Our findings are similar in spirit to Goldstein and Udry (2006) who exploit within household variation to show that while politicians in Ghana benefit from more secure land rights, political control over land allocation leads to more inefficient outcomes.
} 
gether, our findings suggest that there is not a norm of quiet acceptance of politician opportunism but nevertheless electoral incentives are unable to completely constrain the exercise of self-interest by politicians. ${ }^{8}$

The remainder of the paper is organized as follows. In Section two, we describe the institutional setting and in Section three we provide a theoretical framework which motivates our empirical analysis. Our empirical method and results are reported in Section four. Section five concludes.

\section{Background}

A 1993 constitutional amendment made a three-tier elected local government obligatory throughout India. Our focus is on the lowest tier of local self-government - a popularly elected village council, called the Gram Panchayat (GP).

Our empirical study focuses on the four South Indian states of Andhra Pradesh, Karnataka, Kerala and Tamil Nadu. Each Indian state separately decided which policies to decentralize to the GP and how to demarcate the physical boundaries of a GP. Apart from Kerala, where each village is mandated as a separate GP, all other states in our sample use a population criterion. ${ }^{9}$ In all cases a GP is subdivided into wards (the population per ward varies between 300 and 800) and elections are at the ward-level.

The GP council consists of councillors elected from wards and is headed by the Pradhan. In two of our sample states (Andhra Pradesh and Tamil Nadu) the Pradhan is directly elected, while in Karnataka and Kerala he/she is nominated from the pool of elected village councillors.

The 73rd constitutional amendment mandated political reservation of a certain fraction of the Pradhan positions in each state in favor of historically disadvantaged lower castes and women. The historically disadvantaged castes include Scheduled castes and Scheduled tribes (SC/ST) and in two states Other Backward Castes (OBC). Only individuals belonging to the group benefiting from reservation can stand for election in a seat reserved for that group. It also requires that one-third of Pradhan positions in every state be reserved for women while the extent of caste

\footnotetext{
${ }^{8}$ This is consistent with evidence from U.S. Governors (Besley and Case (1995) and List and Sturm (2006)).

${ }^{9}$ The average population per GP is 1650 in Andhra Pradesh, 6500 in Karnataka, over 20,000 in Kerala and 4000 in Tamil Nadu.
} 
reservation reflect the group's population share in the state. No GP can be reserved for the same group in two consecutive elections. Finally, the amendment also mandated the constitution of a village-level supervisory body consisting of all adults registered in the electoral rolls of a GP, the Gram Sabha.

A GP has responsibilities of civic administration with limited independent tax raising powers. ${ }^{10}$ While Panchayat legislation requires that the Pradhan decide the choice of beneficiaries and public good allocation in consultation with villagers and village councillors, final decision-making powers remain vested with the Pradhan. Though the precise scope of GP policy activism varies across states, the GP is typically responsible for beneficiary selection for government welfare schemes and the construction and maintenance of village public goods.

Since 1997 the Indian government has used a targeted public food distribution system which provides Below Poverty Line (BPL) card holders subsidized food while charging a near market price for the others. In 2000-01, for our sample states, the annual income gain from having a BPL card was roughly $5 \%$ of an agricultural labor household's annual expenditure. ${ }^{11}$ In addition to subsidized food, most GP administered welfare schemes, e.g. employment and housing schemes, restrict eligibility to BPL households, and in some cases SC/ST households.

To identify BPL households the GP, together with state government officials, conducts a census. GP politicians bear substantial responsibility for conducting this survey. ${ }^{12}$ They choose the village surveyors, and prepare a preliminary 'BPL' list of recipients. This list is supposed to be finalized at a Gram Sabha meeting. However, in reality politicians enjoy substantial discretion in selecting BPL households and villager oversight is relatively limited. Only $76 \%$ of the villages we surveyed had held a Gram Sabha in the past year, and only $20 \%$ of households report ever having attended a Gram Sabha. Moreover, beneficiary selection was discussed in only $22 \%$ of Gram Sabha meetings (Besley, Pande and Rao (2005)). This is also reflected

\footnotetext{
${ }^{10}$ On average, roughly 10 percent of a GP's total revenue comes from own revenues with the remainder consisting of transfers from higher levels of government.

${ }^{11}$ Under the public food distribution system BPL households enjoy a $50 \%$ subsidy on upto 20 $\mathrm{kg}$ of food grains per month. Planning Commission, (2005) calculations suggest that the effective annual income gain was Rs. 1025 in Andhra Pradesh, Rs. 520 in Karnataka, Rs. 1414 in Kerala and Rs. 809 in Tamil Nadu. We combine these figures with data from the 1999 National Sample Survey to compute the implied income gain for a agricultural household.

${ }^{12}$ The central government uses the Planning Commission's poverty estimates to release food grains to each state. Each state government decides district-wise BPL card quota. Within a district, a BPL quota is determined at the GP level.
} 
in politician perceptions - only $9 \%$ of the 540 politicians who we surveyed stated that the Gram Sabha decided the final BPL list; in contrast, $87 \%$ believed that this power lay with a Panchayat official.

Turning to public good activism, GP officials allocate both the resources raised by taxing households and the funds transferred from the State government. While the category of expenditure for State funds is often specified, the GP has complete discretion over which villages, and within villages which areas, are to benefit from such expenditure.

\section{The Model}

In this section, we provide a simple theoretical structure to mirror the institutional context that we are studying. This yields predictions about how, in a world where politicians are self-interested, we expect politics to affect public resource allocation.

GP politicians control political authority in our villages. The GP is headed by a chief executive, the Pradhan, whom we model as an agenda setter. We examine how the selection procedure for politicians, and institutional constraints on politicians' discretionary policy powers, affects household level transfers within a village and public good allocation across villages within a GP.

\subsection{Framework}

Assume there are $V$ villages in a GP labeled $v=1, \ldots, V$. Let $n_{v}$ be the number of households in village $v$ whom we index $i=1, \ldots, n_{v}$. Each individual $i$ in village $v$ is either rich, $R$, or poor $P$. Let $\lambda(i) \in\{P, R\}$ denote the type of individual $i$, and $\pi_{v}$ the fraction of type $P$ citizens in village $v$. While a gross simplification, studying two types suffices to make the main theoretical points needed to underpin the empirical analysis.

The GP allocates a budget of size $B$ across the villages. Denote village public expenditures by $G_{v}$. Thus:

$$
\sum_{v=1}^{V} G_{v}=B .
$$

Resource allocation is controlled by a village council with a set of representatives one for each village - whose identities are denoted by a vector $\kappa=\left\{\kappa_{1}, \kappa_{2}, \ldots, \kappa_{V}\right\}$. 
$\kappa_{v}=i$ denotes the identity of the individual selected to represent the village in the council and $\lambda\left(\kappa_{v}\right)$ denotes his type.

The council also controls household access to transfers from the state - BPL cards in our case. Each household can receive a transfer $\tau_{i} \in\{0, T\}$ at a cost $c\left(\tau_{i}, \lambda(i), \kappa_{v}\right)$. Costs should be interpreted quite broadly to include efforts of those who wish to receive transfers as well as those who are charged with giving them out. We allow the cost of gaining a transfer to depend on who is elected to represent the village. ${ }^{13}$ This could be because elected representatives exercise self-interest or a group preference - targeting more resources towards certain groups. The preferences of citizen $i$ are quasi-linear in private goods and denoted by:

$$
V\left(\lambda(i), G_{v}\right)+\tau_{i}-c\left(\tau_{i}, \lambda(i), \kappa_{v}\right)
$$

Effective targeting of private transfers towards the poor in village $v$ requires:

$$
c\left(T, R, \kappa_{v}\right)>T>c\left(T, P, \kappa_{v}\right) .
$$

That is, only poor households find it worthwhile to claim transfers. Let

$$
v\left(\lambda(i), \kappa_{v}\right)=\max _{\tau \in\{0, T\}}\left\{\tau-c\left(\tau, \lambda(i), \kappa_{v}\right)\right\}
$$

be the utility from household transfers as a function of the individual's type and the identity of the village representative.

\subsection{The Policy Process}

Within each GP, one elected representative is the Pradhan and possesses agenda setting power. There are two possible methods of Pradhan selection - direct election from the GP as a whole and election from among the elected representatives from each village (indirect election). Following the citizen-candidate approach to elections (Besley and Coate (1997) and Osborne and Slivinski (1996)), we model elections in three stages. At the first stage, any villager can stand as a candidate to represent the village. At stage two, the citizens vote among the self-declared candidates and at the third stage, the council chooses policies. We look for an equilibrium of this

\footnotetext{
${ }^{13}$ While this could, in principle, depend upon the whole vector of council representatives it would significantly complicate the political game laid out below.
} 
game in which voting is strategic and both voting decisions and entry decisions form a Nash equilibrium. We suppose that if nobody is elected then $\kappa_{v}=\varnothing$ and $c(T, P, \varnothing)>T$. There is a small cost of $\delta>0$ of standing as a candidate. We study the model in reverse order, beginning with policy determination.

\section{A. Policy Determination}

Suppose that there is a vector of elected council representatives including the Pradhan. Let $v=\theta$ denote the Pradhan's village. Thus, the outcome of the electoral process is denoted by $\{\theta, \kappa\}$. Without loss of generality, let the Pradhan's village be village 1 . The policy process has two parts which can be studied separately. The allocation of household transfers depends solely on $\kappa_{v}$ as the budget for this is not set by the GP. This was studied above. The allocation of expenditures across villages depends upon $\theta$. It is this that we study now.

The Pradhan will propose an allocation to other council members. This must be agreed to by a majority of council members in order to be accepted. ${ }^{14}$ If the village council cannot agree to a public good allocation, then the status quo is that each district gets at least $\underline{G}$ and the Pradhan's village gets $B-\underline{G}$. Then, each village representative faces a status quo utility level of $V\left(\lambda\left(\kappa_{v}\right), \underline{G}\right)+v\left(\lambda\left(\kappa_{v}\right), \kappa_{v}\right)$ which can depend on the type of the politician in the village. This defines a simple bargaining game between the Pradhan and other elected representatives. The Pradhan knows that he can offer $\underline{G}$ to $(V-1) / 2$ of the villages and get $T-\underline{G} \frac{(V-1)}{2}$ for himself. The remaining villages get nothing which exceeds what he would get in the status quo. While this is simple and extreme, it is indicative of what will happen in a wide variety of circumstances where there is a fixed agenda power. ${ }^{15}$ Thus, resource allocation in the agenda setting model has:

$$
G_{v}^{*}= \begin{cases}B-\underline{G} \frac{(V-1)}{2} & \text { ifv }=\theta \\ \underline{G} & \text { ifv isinthewinningcoalition } \\ 0 & \text { otherwise. }\end{cases}
$$

The key observation from the agenda setter model of a GP is the resource advantage for the Pradhan's village. This defines the allocation as a function $\{\theta, \kappa\}$. This

\footnotetext{
${ }^{14}$ The classic analysis of agenda setting is by Romer and Rosenthal (1978). Riker (1962) first proposed the importance of minimum winning coalitions in legislative bargaining.

${ }^{15}$ Things are more complex in models such as Baron (1992) where agenda setting power varies randomly over time.
} 
model, however, does not predict any link between the Pradhan's type and the allocation and nor does it predict which villages will enter the minimum coalition. We return to this below.

Let $\sigma_{v}$ be an indicator variable that is equal to one in the Pradhan's village, i.e. if $v=\theta$ and zero otherwise. Also, let $\chi_{v}$ be the probability that village $v$ is in the winning coalition if the village is not the Pradhan's village. Putting this together with the allocation of household transfers above, we can determine the overall allocation of transfers. The expected utility of household $i$ in village $v$ as a function of $\left\{\kappa_{v}, \sigma_{v}, \chi_{v}\right\}$ as:

$$
\begin{aligned}
\omega_{i v}\left(\kappa_{v}, \sigma_{v}, \chi_{v}\right)= & \sigma_{v} V\left(\lambda(i), B-\underline{G} \frac{(V-1)}{2}\right) \\
& +\left(1-\sigma_{v}\right)\left[\chi_{v} V(\lambda(i), \underline{G})+\left(1-\chi_{v}\right) V(\lambda(i), 0)\right]+v\left(\lambda(i), \kappa_{v}\right) .
\end{aligned}
$$

The payoff of household $i$ in village $v$ depends solely on the type of the elected representative in his village, i.e. $\kappa_{v}$.

\section{B. Voting}

To study the election outcome, we make two natural assumptions:

Assumption 1: (Political advantage)

$$
c(T, \lambda(i), i)<c(T, \lambda(i), k) \text { for } k \neq i
$$

That is, relative to non-politicians, politicians find it easier to access public transfers. This both leads us to expect politicians to claim public transfers more often than non-politicians and implies that there is rent to holding public office.

Assumption 2: (Type advantage)

$$
c(T, \lambda(i), \ell)<c(T, \lambda(k), \ell) \text { if } \lambda(i)=\lambda(\ell) \neq \lambda(k) .
$$

This says that households find it easier to gain a transfer when a politician of their own type is in office and gives a reason for them to prefer politicians of their own type to hold office. ${ }^{16}$

Suppose that a set of candidates $\mathcal{C}_{v}$ have put themselves forward for office in

\footnotetext{
${ }^{16}$ There are other extensions of the model which deliver this. For example, politicians could influence which kinds of public projects $G_{v}$ is spent on. This would only strengthen our results.
} 
village $v$. Then all voters (weakly) prefer a candidate of their own type if there is one available and are indifferent between candidates in terms of the outcome with respect to $G_{v}$ which depends on $\sigma_{v}$ and $\chi_{v}$. There are typically many Nash equilibria in the voting game since voters are indifferent between multiple candidates. We will pick the Nash equilibrium in which voters coordinate on one candidate of the majority preferred type. Thus, if $\pi_{v} \geq \frac{1}{2}\left(<\frac{1}{2}\right)$ and a poor (rich) candidate stands, then a poor (rich) candidate is elected.

\section{Entry of Candidates}

We now consider an individual's decision to enter as a candidate, and the impact of reservation on this. A candidate will enter only if there is a benefit of doing so in terms of private goods. If $T>c(T, \lambda(i), i)$, then there is no benefit to standing for office. There are two cases to consider.

Case 1: $T>c(T, \lambda(i), i)$ for $\lambda(i)=R$.

In this case, a rich candidate has no incentive to run for office even if the type $R$ 's are a majority. Thus, political competition will be among the poor candidates.

Proposition 1 In case 1, in any Nash equilibrium of the citizen-candidate entry game, all candidates are of type $P$. The equilibrium number of candidates is strictly positive for small enough $\delta$ and is given by:

$$
n^{*}=\operatorname{int}\left(\frac{c(T, P, k)-c(T, \lambda(i), i)}{\delta}\right)-1
$$

In this world, candidate entry serves purely as a rent dissipation device - sufficient entry by candidates reduces the private benefits to zero. Note, however, that who holds political office does not affect targeting since type $P$ candidates would have claimed a transfer for their household anyway. In this equilibrium, reservation for group $P$ will also not alter the outcome as they have sufficient incentive to run for office.

Case 2: $c(T, \lambda(i), i)>T>c(T, R, k)$ for $k \neq i$ and $\lambda(i)=R$.

In this case, a rich candidate who holds public office will claim a transfer that he would not have claimed otherwise. This gives an incentive for a type $R$ candidate to run for office. However, he or she only has a chance of being elected against a type $P$ candidate if type $R$ 's are in a majority. If type $P$ 's are in a majority, then the outcome is as in Proposition 1. However, if type $R$ 's are in a majority, we have: 
Proposition 2 In case 2, in any Nash equilibrium of the citizen-candidate entry game and $\pi_{v}<\frac{1}{2}$, all candidates are of type $R$. The equilibrium number of candidates is strictly positive for small enough $\delta$ and is given by:

$$
n^{*}=\operatorname{int}\left(\frac{T-c(T, \lambda(i), i)}{\delta}\right)-1
$$

In this case, politicians are an economic elite. However, they are motivated to run for office by the spoils that they obtain once they are there. Thus, all else equal, we expect that politician households are more likely to receive a BPL card. This political equilibrium has an interesting testable implication of political reservation for politicians of type $P$. Since they already qualify for BPL cards, we should not expect to see any change in their ability to obtain BPL cards.

Corollary In case 2, reserving a seat for a type $P$ politician will not alter his probability of possessing a BPL card.

We have assumed that the only benefit from holding public office is through changing the costs of obtaining a BPL card, which is patently simplistic. However, even in a richer model with a wider array of motives to stand for office, we would still expect the effects that we have identified - reduced cost of access to BPL cards for politicians, and the effect of reservation on BPL targeting to be at work on the margin. In this spirit, we will test for the impact of holding office on household access to BPL cards below.

Proposition 2 is a case where the economic elite are in office based on their numerical superiority. However, there are other possible reasons why this could be the case. For instance, entry costs into political office by the poor group may be sufficiently prohibitive so that only rich candidates stand. It may also be that the rich group is able to find other means of monopolizing the candidate entry process. In this case, Proposition 2 will be valid more widely, i.e. even when $\pi_{v}>1 / 2$.

\subsection{The Pradhan's Village}

The model as stated is largely silent on the determination of $\sigma_{v}$ and $\chi_{v}$. Moreover in the data, we only observe which village has the Pradhan and not the structure of any winning coalition. That said, it is useful that, in the framework that we have 
laid out, the determination of the Pradhan's village can be studied separately from determining which type (rich or poor) will hold office.

In practice, there are two institutional arrangements - direct election of the Pradhan and election from among the GP members. As a benchmark, we consider a simple model where the Pradhan is chosen from among a set of candidates, with each village having (atleast) one candidate. In the case of direct election, it is clear that the largest village in the GP will have an advantage. With indirect elections, the village with the most wards should win the Pradhan's office. However, since the number of wards in a village is essentially determined by its population size, the choice of institutional arrangement should not make much difference in practice. The bottom line is that larger villages should enjoy an electoral advantage. ${ }^{17}$

This simple model, however, ignores the possibility of coalition formation during the electoral process. A candidate in one village may withdraw from the race for Pradhan and deliver the votes from his village to another candidate in exchange for belonging to a winning coalition ex post. For example, with three villages of equal size a candidate from one village could drop out with a coalition of two-third of the voters forming behind a remaining candidate. This would be credible if the winning candidate could reward the village whose candidate dropped out. A coalition proof equilibrium would then be one where there is no candidate who could drop out of the race and benefit in this way. Following this logic, we should expect each Pradhan to assemble a minimal winning coalition in which he gets (just over) half the support of either the voters or the village councillors in a GP.

There are typically many winning coalitions possible for any given allocation of population across villages. For example, in the case of three villages with a third of the population each, there are six possible winning coalitions each containing twothirds of the population. A village is the Pradhan's village in two out of these six coalitions. But there is no obvious reason to expect any one of these coalitions to prevail in practice. In order to remain agnostic about which coalition will form, we choose an ex ante measure of the each village's "power" by computing the fraction of winning coalitions (i.e. with more than half the population) formed from among all villages in a GP in which that village is decisive in maintaining a coalition containing $50 \%$ of the GP population. A coalition with more than half the GP population is

\footnotetext{
${ }^{17}$ In a citizen-candidate game with candidates running for the job of Pradhan, with a positive but sufficiently small cost of entry there is an equilibrium where a candidate from the largest village is elected unopposed.
} 
assumed to be winning with the Pradhan being chosen randomly from among the coalition partners. In an ex ante sense, we expect villages with a larger power score of this kind to have a greater chance of being the Pradhan's village ex post. A village is more powerful if there are more coalitions in which it is decisive.

On this basis, any village with more than half the GP population has a power score of one. In a One or Two village GP a single village is powerful. The interesting cases arise for GPs with more than two villages in which case the power of a village is a non-linear function of the vector of village populations.

We conjecture that the power variable is a determinant of $\sigma_{v}$ and $\chi_{v}$, and will explore empirically whether a village's power score predicts whether it will become the Pradhan's village. We can also test whether its impact differs between direct and indirect election states, and also whether, independent of the pattern of political control, power influences final resource allocation.

\section{Data}

Our analysis uses survey data from over 500 villages which we collected between September and November 2002. The sample villages are distributed across nine boundary districts in the four southern states of India - Andhra Pradesh, Karnataka, Kerala and Tamil Nadu. ${ }^{18}$ We randomly sampled six GPs in three blocks (the administrative unit below the district) in each district. In GPs with less than four villages, we sampled all villages; otherwise, we sampled the Pradhan's village and two randomly selected villages. ${ }^{19}$

In every sampled village we conducted a village meeting at which we obtained information on village demographics and public good provision, and surveyed an elected Panchayat official. In the Pradhan's village the Pradhan was interviewed, otherwise we interviewed a randomly selected village councillor. In a random subsample of three GPs per block (259 villages) we conducted household interviews in surveyed villages. We surveyed twenty households in each village where we required that four of these be SC/ST households. Household selection was random, and we alternated between male and female respondents.

\footnotetext{
${ }^{18}$ At the time of survey at least one year had lapsed since the last GP election in every surveyed state.

${ }^{19}$ In Kerala to account for the higher GP population we sampled 3 GPs per block and 6 wards per GP - the Pradhan's ward and five randomly selected wards.
} 
Table 1 provides descriptive statistics. While the average respondent has over four years of education, politicians are significantly more educated. Average land holdings are 2.2 acres; however, among politicians this figure rises to 5.7 acres. Politicians elected from non-reserved seats are significantly more landed than those elected from reserved seats. Only seven percent of our respondents, but a quarter of the politicians, belong to a family where someone held a political position. Finally, twenty-one percent of the households, and a quarter of the politician households possess a BPL card. Thus while, for the most part, politicians are from the political and economic elite it appears that they have a greater chance of having a BPL card than a randomly selected non-politician household.

Respondents are on the whole critical of their local politicians - less than $40 \%$ believe the Pradhan looks after village needs or keeps election promises. Less than $10 \%$ of the respondents believe that their village facilities are better than in neighboring villages.

Turning to village level variables, roughly $16 \%$ of our GPs each are (separately) reserved for women and SC/STs (this translates into $54 \%$ of the sampled villages having a reserved Pradhan). Within a block, reservation of the Pradhan position and of wards within a village, is by rotation and is exogenous to village characteristics. ${ }^{20}$

Our analysis examines how politics affects the targeting of BPL cards and public good activism. To measure public good activism we use information on the number of investments in different public services which was collected during the village meeting. We collected this data for the following categories: roads, village transport, water, sanitation, irrigation, electricity, education and health. For each category, we construct a count variable denoting how many investments occurred in the village since the last GP election. We then construct a standardized investment measure for each category (z-score) by subtracting the mean for non-Pradhan villages and dividing by the corresponding standard deviation.

We are interested in how public good activism varies across villages in a GP. To measure the electoral clout of village $v$ in a GP with $n$ villages we consider all coalitions of size $<n$ with population greater than or equal to half the GP population as winning coalitions. The own coalition of village $v$ is the number of winning coalitions which include $v$ and no longer remain a winning coalition when $v$ is removed. For

\footnotetext{
${ }^{20}$ No political position can be reserved for the same group for two consecutive elections. In Besley, Pande, Rao and Rahman (2004) we show that public good provision in 1991 was statistically indistinguishable in GPs with and without a reserved Pradhan.
} 
each village we construct a variable "power" which is the ratio of own coalition $v$ to the total number of winning coalitions in the GP. The average village in our sample belongs to $39 \%$ of the winning coalitions in the GP. Finally, we measure the political clout of village by whether it is the Pradhan's village (i.e. the Pradhan lives in it).

\section{Empirical Analysis}

The model identifies policy outcomes with the exercise of political authority. The result is a probability distribution over the village level allocation of public goods $\left\{G_{1}, . ., G_{V}\right\}$, and the targeting of transfers $\left\{\tau_{1 v}, \ldots, \tau_{n_{v} v}\right\}$. In our model the exercise of political authority implies:

- The Pradhan's village will receive a larger share of Panchayat resources than other villages in the GP.

- If politicians belong to the richer sections of society then they are more likely to have a BPL card.

- Households are more likely to have a BPL card when a politician of their group is in office.

We next explore these issues. As background, we first examine the correlates of being a politician and of being in the Pradhan's village. We then look at whether the structure of political authority affects individuals' and villages' propensity to receive state provided goods.

\subsection{Selection}

\section{A. Holding Political Office}

We start by using our household data to ask whether individual characteristics affect the likelihood that the respondent is an elected politician in our survey. We estimate a linear probability model of the form

$$
p_{i v}=\alpha_{v}+\rho x_{i v}+\varepsilon_{i v}
$$


where $p_{i v}$ is a dummy variable for whether respondent $i$ is a politician in village $v$, $\alpha_{v}$ is a village fixed effect and $x_{i v}$ is a vector of individual and household characteristics. Thus, we exploit within-village variation to estimate effect of household and individual characteristics. Standard errors are clustered at the village-level.

Table 2 reports the results. In column (1) we see that an additional year of education, and owning an additional acre of land, each increase the likelihood that the respondent is a politician by roughly $0.8 \%$. A respondent belonging to a family with a history of political participation is $12 \%$ more likely to be a politician. ${ }^{21}$

In columns (2) and (3) we separately examine the propensity of being elected to a reserved and unreserved position. In both cases we observe positive selection on education and family political history. ${ }^{22}$ However, reserved politicians are not more landed than the average citizen. Such politicians are, however, significantly more likely to be female or SC/ST reflecting the fact that these are the two groups which benefit from political reservation. In columns (4)-(6) we restrict the sample to Pradhan villages, and the dependent variable to whether the respondent is the Pradhan. We observe very similar patterns of selection.

These confirm the impression formed in the raw data reported in Table 1 that politicians are from a political and economic elite. This conclusion is weaker for politicians who are elected from reserved seats. ${ }^{23}$ In terms of the theory above, the results point to a political equilibrium of the kind studied in Proposition 2 where candidates for political office are mostly not poor. It will, therefore, be interesting to see whether politicians do use their access to public office to award themselves BPL cards.

\section{B. Selection of Pradhan Village}

To examine this empirically we estimate the following village-level linear probability model:

$$
P_{v g b}=\beta_{b}+\delta_{1} X_{v g b}+\eta_{v g b}
$$

\footnotetext{
${ }^{21}$ We have also estimated these regressions including party affiliation variables. A respondent affiliated with the party in power in the state is roughly $7 \%$ more likely to be a politician.

${ }^{22}$ Further disaggregation shows that family political history is positively correlated with selection only for women. The absence of a political history effect for SC/STs reflects the recent entry of these groups in politics on the back of reservation.

${ }^{23}$ Village meeting data also shows that reservation significantly reduces the likelihood that the Pradhan is an economic or political oligarch.
} 
$P_{v g b}$ is a dummy variable for village $v$ in GP $g$ in block $b$ which is equal to one if the Pradhan lives in that village. We use $\beta_{b}$ to denotes block fixed effects and $X_{v g b}$ is a vector of village characteristics. These regressions exclude Kerala since all GPs in this state contain one village and hence are, by definition, the Pradhan's village. We cluster standard errors at the GP level.

The results are in Table 3. As we have conjectured, larger villages fair well in competition for the Pradhan's chair. A 1\% increase in village population increases the probability that the village is the Pradhan's village by $0.24 \%$ (column (1)). In column (2) we see that the effect of village population does not vary across states with indirect and direct elections. In column (3) we include other measures of a village's political power - whether the village is the GP Headquarter and the number of wards in the village. Both variables are positively correlated with village population. They are also significant determinants of being the Pradhan's village; however, the effect of village population is robust to their inclusion.

In columns (4)-(6) we investigate the importance of a village's relative population share within a GP. Since GP elections are based on plurality rule, a village's relative population share should be the relevant determinant of which village captures the Pradhan's chair. The simplest way to see this is to include GP fixed effects. Within a GP, a $1 \%$ increase in village population increases the likelihood that it is the Pradhan's village by $0.27 \%$ (column (4)). The next two columns consider more structured forms of estimating the impact of a village's population share. In column (5) we see that a $1 \%$ increase in the share of GP population living in a village increases its likelihood of being the Pradhan's village by $0.6 \%$. In column (6) we measure a village's population influence within a GP by its 'power' - the percentage of winning coalitions in the GP that a village belongs to. This variable positively predicts Pradhan village, and its inclusion renders the effect of a village's own population variable insignificant. The effect of power is large - a move from a power of one to a power of one-third reduces the probability of being the Pradhan's village by roughly $25 \%$. Finally, the effect of power is similar across states with direct and indirect elections. ${ }^{24}$

Overall, these results strongly suggest that political geography influences the location of the Pradhan's village. At the very least, it will be important to control for these when we investigate whether living in the Pradhan's village yields a benefit

\footnotetext{
${ }^{24}$ This last specification is available from the authors.
} 
in terms of policy activism.

\subsection{Policy Choice}

We now examine how political forces shape policy outcomes - both across households within a village and across villages in a GP.

\section{A. Targeting Transfers between Households}

The basic idea of the BPL card program is to help disadvantaged groups. The fact that politician households are wealthier than non-politician households (Tables 1 and 2) ought therefore to imply that politician households are less likely to have a BPL card.

To investigate this empirically, let $b_{i v}$ be an indicator variable denoting whether household $i$ in village $v$ has a BPL card. We estimate a linear probability model:

$$
b_{i v}=\alpha_{v}+\gamma x_{i v}+\eta_{i v}
$$

where $x_{i v}$ is a vector of household characteristics that are relevant to whether the household is needy. We also include an indicator variable for whether the household has a history of political involvement. The influence of village-level characteristics are subsumed in a village fixed effect $\alpha_{v}$ so this equation only exploits within village variation in individual and household characteristics to explain BPL targeting. The standard errors are clustered at the village level.

The results are in Column (1) of Table 4. BPL cards are, on average, targeted towards disadvantaged groups (as measured by caste and landownership). An $\mathrm{SC} / \mathrm{ST}$ household is $16 \%$ more likely to get a BPL card and a landless household $7 \%$ more likely. Households with a more educated respondent are less likely to get a BPL card. Households in which at least one member holds, or has previously held, political office are no more likely to have BPL card.

To test the role of current political control, column (2) includes as a regressor whether the household contains a currently elected GP politician. Consistent with the view that holding public office reduces the cost of access to such cards for politicians, we find that politician households are roughly $8 \%$ more likely to have a BPL card.

Voters could ultimately sanction politicians who behave opportunistically by vot- 
ing them out of office. However, our data do not permit us to look at this. However, we are able to investigate whether particular characteristics of politicians mitigate their opportunism. In column (3) we find that this effect is essentially limited to unreserved politicians, and there is no significant difference in the propensity of village councillors and Pradhans to have a BPL card. Relative to unreserved politicians, politicians elected from unreserved seats are more likely to be new entrants to politics, and enjoy less political and economic advantage. This finding is most likely a selection effect rather than reserved politicians facing better incentives. If anything, the fact that reservation status of the council position only lasts a single election cycle makes it less likely that reserved politicians will be successful if they stand for re-election. These results are consistent with the political equilibrium being something along the lines of Proposition 2 with an elite benefiting from control of public resources in unreserved seats. ${ }^{25}$ It is, however, interesting that political opportunism does, in column (3), appear to be lower when politicians are more educated.

Finally, in column (4) we show that living in the Pradhan's village does not affect a household's propensity to receive a BPL card. ${ }^{26}$ This regression includes block fixed effects. This is in line with our conjecture in the theory section which allowed us to treat the two different aspects of public resource allocation - household and village - separately.

The evidence in Table 4 suggests that while the BPL program does succeed in targeting the relatively disadvantaged households in a village (as measured by $\mathrm{SC} / \mathrm{ST}$ and landless status), politician households also benefit from this program.

The theory suggested that the cost of targeting and hence its effectiveness might depend on politicians' characteristics. In Table 5 we investigate this by looking at how village and politician characteristics influence targeting to disadvantaged households. We do so by interacting Pradhan and village characteristics with being either an SC/ST or a landless household in the targeting equation. ${ }^{27}$

\footnotetext{
${ }^{25}$ In line with what the theory predicts, the reservation effect comes from SC/ST reservation rather than reservations for women.

${ }^{26}$ Estimating this specification as a probit leaves the results unchanged.

${ }^{27}$ It is unclear whether villages face a binding budget constraint for BPL cards. To the extent that there is flexibility in the number of BPL cards that can be allocated at the village level, these results can be interpreted as the consequences of selecting politicians of different quality who care more or less about the poor. The theory could be extended to accommodate this using a political agency model with adverse selection where there is some probability of a politician in group $R$ being a good type who cares about targeting the poor or a self-interested type who does not.
} 
The first three columns of Table 5 examine how Pradhan characteristics affect BPL card allocation. The likelihood that the average landless household has a BPL card is lower when the Pradhan has a BPL card. This suggests a potential welfare cost with opportunistic politicians targeting landless households less. In contrast, landless households appear to benefit from having a more educated Pradhan. This is further evidence that having educated politicians improves household level targeting in this setting. Having a reserved politician does not impact a landless household's propensity to get a BPL card. It does, however, significantly increase the likelihood that a SC/ST household has a BPL card (column 3). This confirms the idea that individuals do tend to benefit when there are politicians in office whose characteristics are more similar to their own.

Finally, in column (4) we examine Pradhan village effects. Living in the Pradhan's village leaves a household's propensity to receive a BPL card unaffected again confirming the idea that the Pradhan village effect ought not to be important for this level of targeting.

\section{B. Allocation between Villages}

We now examine resource allocation across villages.

Let $Y_{v g k}$ be the standardized measure of GP activism for activity $k$ in village $v$ in GP $g$. We estimate a regression of the form:

$$
Y_{v g k}=\beta_{b}+\rho P_{v g k}+\pi X_{v g k}+\varepsilon_{v g k}
$$

where $\beta_{b}$ are block fixed effects, $P_{v g k}$ is an indicator variable equal to one if the observation is for the Pradhan's village and $X_{v g k}$ are the village control variables used to explain the Pradhan's village above. Standard errors are estimated allowing for clustering at the GP level.

The categories of activism that we study are roads, transport, water, education, health, sanitation, electricity, and irrigation. Our standardized measure - the construction of which was discussed in the data section - allows us to compare results across subcategories. Finally, following Kling et al (2007), we obtain an overall index by taking the average of equally-weighted standardized components of these activism measures. To estimate the covariance matrix (for both subcategories and the overall index) we use the seemingly unrelated regression (SUR) model. The results are reported in Tables $6 \mathrm{a}$ and $6 \mathrm{~b}$. 
Column (1) of Table 6a shows that, as predicted by an agenda setting model, being the Pradhan's village is positively correlated with overall GP activism. The rest of Table 6 a reports alternative specifications which check whether the Pradhan village effect is robust to the inclusion of the village characteristics which influence a village's probability of securing the Pradhan's position (on this, see Table 3). The regression in column (2) includes GP fixed effects and as covariates other determinants of Pradhan village location within the GP. Encouraging to the view that we are picking up the effect of political control, the Pradhan village effect remains positive and significant. It is also the case that the population variables are jointly significant determinants of activism. The Pradhan village effect, however, remains evident also when, as reported in column (3), we include the village power variable. It is striking that, although this variable strongly predicts which village will be the Pradhan's village, it does not appear to influence policy outcomes. Columns (4) and (5) provide two further checks on this finding. In column (4) we report results which exclude Kerala without any material impact on the findings. In column (5) we exclude the Pradhan village variable. The population effect is significant, and it appears that including the Pradhan village effect is (as expected) partially picking up the electoral influence of population.

Columns (1)-(8) of Table $6 \mathrm{~b}$ report results for different categories of GP activism. These suggest that the Pradhan village effect is mainly being driven by activism in roads and water - two important areas of investment by GPs. In no case does the power variable predict GP activism (and nor does being the GP headquarters). However, there does appear to be an effect of village size over and above the Pradhan village effect in the case of roads.

Overall, the results in Tables $6 \mathrm{a}$ and $6 \mathrm{~b}$ are consistent with the Pradhan's village enjoying a policy advantage in the GPs that we are studying.

Since we only have cross-sectional data we cannot directly compare public good provision in 2002 with that before the Panchayat system was instituted. However, as a baseline in Appendix Table 1 we consider a set of 1961 and 1991 village public goods as measured in the censuses taken in these years. For consistency, we construct standardized z-scores for each subcategory following the procedure outlined above and estimate the regressions in a SUR framework. In no case do we find that the Pradhan village is doing better. Instead the main positive predictor of public good provision appears to be village population. This further supports the notion that the Pradhan village effect is picking up something about the contemporary level of 
government activism.

In Table 7 we examine whether the Pradhan village effect is influenced by either Pradhan or village characteristics. This is interesting as means of seeing whether there are some particular types of Pradhan who are driving the result. The results show no evidence that Pradhan characteristics, as measured by whether he/she has a BPL card, years of education or reservation status, influence public good allocation. The method of election of the Pradhan also seems not to have any impact on activism. Taken together these results further underpin the proposition that it is agenda setting power pure and simple that matters for policy.

Table 8 takes a different tack and examines whether being the Pradhan's village is correlated with greater political activism and that this, rather than political control, underlies the results. Our survey asked various questions about villagers' political involvement. If political control is what underlies public good activism, then we would not expect to see higher villager involvement in the Pradhan's village. In fact, neither newspaper readership (column 1), party affiliation (column 2) or attending village meetings (column 3) is higher in the Pradhan's village. Thus political activism appears similar across the Pradhan's and other villages in a GP. Column (4) confirms that political knowledge is also similar across villages with the probability of being able to name one's legislator being no higher in the Pradhan's village than other villages. But when it comes to knowing who the Pradhan is, and having seen him/her, the results are quite different (columns (5) and (6)). Members of the Pradhan's village are significantly more likely to be able to name the Pradhan and to have encountered him/her.

Taken together, the results in Table 8 militate against the view that the Pradhan village effect proxies for a omitted village level political activism variable. Rather, it appears that the agenda setting power conferred on the Pradhan provides an important source of policy advantage to the village in which he or she lives.

\section{Evidence from Attitudes}

Finally, we consider whether household attitudes towards policy mirror the findings based on studying resource allocation directly. Table 9 documents villager perceptions of whether the Pradhan looks after village needs and keeps his/her election promises. We also look at villagers' evaluation of facilities in their own village, relative to those in neighboring villages. In order to study the impact of village level 
characteristics our regressions include block rather than village fixed effects.

Formally, let $q_{i v g}$ be the probability that villager $i$ in village $v$ is satisfied with his GP $g$ 's performance. We model this with the following linear probability model:

$$
q_{i v g b}=\alpha_{b}+\gamma x_{i v g b}+\delta Z_{g b}+\eta_{i v g b}
$$

where $\alpha_{b}$ are block fixed effects, $x_{i v g b}$ are individual and household characteristics and $Z_{g b}$ are GP characteristics. Standard errors are estimated allowing for clustering at the GP level.

The first two rows in Table 9 shows that villagers are more dissatisfied with the performance of the Pradhan if he has a BPL card. However, in line with our results above, respondents think well of educated Pradhans. Both of these results mirror our findings on the Pradhan's ability to allocate BPL cards to disadvantaged households in the village. However, BPL card ownership or level of education for Pradhan seems to have no bearing on whether survey respondents believed that village facilities were better than neighboring villages.

The third column in each case gives an interesting perspective on reserved politicians who are perceived as worse than unreserved politicians in terms of looking after needs and keeping election promises. Given that such politicians seemed less opportunistic than unreserved and were equally good (as Pradhans) in being policy activists, this finding is surprising. It could be that this finding reflects more general negative attitudes towards reservation that transcend performance while in office (on this, also see Duflo and Topalova (2005)). In line with this, we also observe no correlation between views about the quality of village public services and having a reserved Pradhan.

When it comes to being in the Pradhan's village a consistent pattern emerges across all three attitudinal measures with the Pradhan's village having a more positive attitude towards the Pradhan and their perception of village facilities. These results support the idea that the agenda setting effect underlies greater activism in the Pradhan's village.

Taken together, our perception-based results reinforce our findings on policy outcomes. Opportunistic politicians are perceived as worse, a finding which goes against the hypotheses that self-serving politicians are better at serving their constituents or that villagers condone political corruption. 


\section{Concluding Comments}

There is general agreement that India has far to go in improving the quality of its infrastructure and public service delivery, especially in rural areas (Pritchett et al (2006)). The high incidence of poverty in rural India also places a premium on effective targeting of household transfers. In view of this, the 1993 amendment which strengthened local democracy in India held promise to deal with both of these issues. Thus understanding how local governments shape resource allocation is important.

In this paper, we have examined how political influence is used in allocating public resources in a sample of south Indian villages. The analysis has investigated both between and within village resource allocation. The patterns that we have found are robust and transparent - political influence is used exactly as one might expect when politicians enjoy considerable discretionary authority and use it to further their political self interest. Politicians are opportunistic in receiving household transfers and use their agenda setting power to allocate more resources to their own village. This is very much politics as usual.

However, we caution against translating these findings about the importance of self-interest in resource allocation into unremitting cynicism about the Indian experiment with decentralization. Without a counterfactual, we have no way of evaluating the current system relative to alternatives. Moreover, the analysis does suggest that political institutions do have the potential to affect the extent and type of politician opportunism. Greater use of monitoring of politicians' use of BPL cards is a case in point. ${ }^{28}$ But there is also a case for making sure that institutions are designed to rotate the Pradhan's village so that the advantage evens out over time.

More generally, the paper serves as a reminder that, before grander questions about the merits of decentralization can be sorted out, it is necessary to understand the resource allocation process at the local level. Whether looking at national or local politics, the issue is how political incentives are shaped by institutions and how the latter can be structured to achieve a desirable outcome on specific policy dimensions.

\footnotetext{
${ }^{28}$ Besley, Pande and Rao (2005) suggest that better enforcement of the requirement to hold village meetings (Gram Sabhas) may also have a role to play in this.
} 


\section{References}

[1] Ban, Radu and Vijayendra Rao, [2007], "Tokenism Versus Agency: The Impact of Women's Reservations on Panchayats in South India," forthcoming in Economic Development and Cultural Change.

[2] Bardhan, Pranab, [2002], "Decentralization of Government and Development," Journal of Economic Perspectives, 16(4), 185-205.

[3] Bardhan, Pranab and Dilip Mookherjee, [2000], "Capture and Governance at Local and National Levels," American Economic Review, 90(2), 135-139. not cited

[4] Bardhan, Pranab and Dilip Mookherjee, [2003], "Political Economy of Land Reforms in West Bengal 1978-98," mimeo Boston University.

[5] Baron, David, [1991], "Majoritarian Incentives, Pork Barrel Programs and Procedural Control," American Journal of Political Science, 35(1), 57-90.

[6] Barro, Robert, [1973], "The Control of Politicians: An Economic Model," Public Choice, 14, 19-42.

[7] Baqir, Reza, [2002], "Districting and Government Overspending," Journal of Political Economy, 110(6), 1318-1354.

[8] Besley, Timothy and Anne Case, [1995], "Does Political Accountability Affect Economic Policy Choices? Evidence From Gubernatorial Term Limits, Quarterly Journal of Economics 110(3), 769-98.

[9] Besley, Timothy and Stephen Coate, [1997], "An Economic Model of Representative Democracy," Quarterly Journal of Economics, 112(1), 85-114.

[10] Besley, Timothy, Rohini Pande, Lupin Rahman and Vijayendra Rao. [2004a], "The Politics of Public Good Provision: Evidence from Indian Local Governments," Journal of the European Economics Association, 2(2-3), 416-426.

[11] Besley, Timothy, Rohini Pande, Lupin Rahman and Vijayendra Rao, [2004b], "Decentralization in India: A Survey of South Indian Panchayats," unpublished typescript.

[12] Besley, Timothy, Rohini Pande and Vijayendra Rao, [2005], "Participatory Democracy in Action: Survey Evidence from India," Journal of the European Economics Association, 3(2-3):648-657. 
[13] Bradbury, John Charles and E. Frank Stephenson, [2003], "Local government structure and public expenditures," Public Choice, 115, 186-198.

[14] Chattopadhyay, Raghabendra and Esther Duflo, [2004a], "Women as Policy Makers: Evidence from a India-Wide Randomized Policy Experiment," Econometrica , 72(5), 1409-1443.

[15] Chattopadhyay, Raghabendra, Esther Duflo and Greg Fischer, [2006], "Efficiency and Rent-seeking in Local Governments," mimeo MIT.

[16] Chaudhuri, Shubham, [2003], "What difference does a constitutional amendment make? The 1994 Panchayati Raj Act and the attempt to revitalize rural local government in India," typescript, Columbia University. not cited

[17] Crook, Richard C. and James Manor. (1998) Democracy and Decentralization in South Asia and West Africa : participation, accountability, and performance. Cambridge ; New York : Cambridge University Press.

[18] Duflo, Esther and Petia Topalova, [2004], "Unappreciated Service: Performance, Perceptions, and Women Leaders in India," mimeo, MIT.

[19] Enikolopov, Ruben and Ekaterina Zhuravskaya, [2004], "Decentralization and Political Institutions," unpublished typescript.

[20] Faguet, Jean Paul, [2004], "Does Decentralization Increase Responsiveness to Local Needs? Evidence from Bolivia," Journal of Public Economics, 88, 867-894.

[21] Fisman, Raymond and Edward Miguel, [2007], "Corruption, Norms and Legal Enforcement: Evidence from Diplomatic Parking Tickets*," Journal of Political Economy, forthcoming.

[22] Foster, Andrew and Mark Rosenzweig, [2001], "Democratization, Decentralization and the Distribution of Local Public Goods in a Poor Rural Economy," unpublished typescript.

[23] Goldstein, Markus and Christopher Udry, [2006], "The Profits of Power: Land Rights and Agricultural Investment in Ghana," unpublished typescript.

[24] Kling, Jeffrey and Jeffrey B. Liebman, and Lawrence F. Katz, [2007], "Experimental Analysis of Neighborhood Effects," Econometrica, 75, 83-119.

[25] List, John and Daniel Sturm, [2006], "How Elections Matter: Theory and Evidence from Environmental Policy," Quarterly Journal of Economics, 121(4), 
1249-1281.

[26] MacDonald, Lynn and Tim R. Sass, [2005], "The impact of government structure on local public expenditures," unpublished typescript, Florida State University.

[27] Oates, Wallace, [1972], Fiscal Federalism, Harcourt Brace: New York.

[28] Olken, Ben, [2006], "Corruption Perceptions vs. Corruption Reality," NBER Working Paper 12428.

[29] Osborne, Martin J. and Al Slivinski, [1996], "A Model of Political Competition with Citizen Candidates," Quarterly Journal of Economics, 111(1), 65-96.

[30] Pande, Rohini, [2003], "Minority Representation and Policy Choices: The Significance of Legislator Identity," American Economic Review; 93(4), 11321151.

[31] Pande, Rohini, [2007], "Understanding Political Corruption in Low Income Countries," Handbook of Development Economics; Volume 4.

[32] Platteau, Jean-Philippe, [2004], "Monitoring Elite Capture in Community Driven Development," Development and Change 35 (2), 223-246.

[33] Pritchett, Lant and Rinku Murgai and Marina Wes, [2006], "Building on Success: Service Delivery and Inclusive Growth," World Bank India Development Policy Review, New Delhi: MacMillian Press.

[34] Riker, William, [1962], The Theory of Political Coalitions, Yale University Press: New Haven.

[35] Romer, Thomas and Howard Rosenthal [1978], "Political Resource Allocation, Controlled Agendas, and the Status Quo", Public Choice, 33 (4), 27-43.

[36] Triesman, Daniel, [2007], The Architecture of Government: Rethinking Political Decentralization, Cambridge: Cambridge University Press.

[37] Weingast, Barry, Kenneth Shepsle and Christopher Johnson, [1981], "The Political Economy of Benefits and Costs: A Neoclassical Approach to Distributive Politics," Journal of Political Economy, 89, 642-664. 


\section{Appendix A: Sampling}

Besley, Pande, Rahman and Rao (2004b) provides a full description of our sampling strategy. Below we describe the main elements of the sampling procedure relevant to our analysis.

For each state pair two districts (one per state) which shared a common state boundary were selected. Within each pair the three most 'linguistically similar' block pairs (defined in terms of households' mother tongue using 1991 census block level language data) were selected.

We purposively sampled 3 blocks per district, and randomly sampled six GPs per block except in Kerala where we sampled 3 GPs per block. Our sample consists of 201 GPs across 37 blocks. We sampled all villages in GPs with three or fewer villages, otherwise we sampled the Pradhan's village and two other randomly selected villages. We excluded villages with less than 200 persons from our sampling frame and considered hamlets with population over 200 as independent villages.

In every sampled village we conducted a detailed village meeting and a household survey with one elected Panchayat official. If the Pradhan lived in the village he/she was interviewed, otherwise a randomly selected village councillor. In a random subsample of 3 GPs per block we conducted household interviews in all sample villages (259 villages). ${ }^{29}$ In Kerala we randomly selected 2 GPs in one block and one GP in the other block (the selection of which block to sample how many GPs from was also random), and within sampled GPs we conducted household interviews in all sampled wards. Twenty households were sampled per village, of which four were $\mathrm{SC} / \mathrm{ST}$.

\footnotetext{
${ }^{29}$ The survey team leader walked the entire village to map it and identify total number of households. This determined what fraction of households in the village were to be surveyed. The start point of the survey was randomly chosen, and after that every Xth household was surveyed such that the entire village was covered (going around the village in a clockwise fashion).
} 
Table 1: Descriptive Statistics

\begin{tabular}{|c|c|c|c|c|c|}
\hline & \multirow{2}{*}{$\begin{array}{c}\text { Overall } \\
\text { Mean }\end{array}$} & \multirow{2}{*}{$\begin{array}{c}\text { Non- } \\
\text { politicians }\end{array}$} & \multicolumn{3}{|c|}{ Politicians } \\
\hline & & & All & Unreserved & Reserved \\
\hline \multicolumn{6}{|l|}{ Household sample } \\
\hline \multicolumn{6}{|l|}{ Respondent characteristics } \\
\hline \multirow[t]{2}{*}{ Years of Education } & 4.49 & 4.33 & 7.28 & 8.00 & 6.22 \\
\hline & $(4.55)$ & (4.49) & (4.36) & (3.91) & (4.75) \\
\hline \multirow[t]{2}{*}{ Land owned } & 2.26 & 2.07 & 5.71 & 6.90 & 3.96 \\
\hline & (4.77) & (4.38) & (8.24) & $(9.20)$ & (6.18) \\
\hline \multirow{2}{*}{ Family political history } & 6.70 & 5.70 & 25.70 & 23.70 & 29.00 \\
\hline & $(25.00)$ & $(23.20)$ & $(43.70)$ & $(42.60)$ & $(45.40)$ \\
\hline \multirow[t]{2}{*}{ SC/ST } & 22.90 & 23.00 & 22.96 & 5.60 & 48.40 \\
\hline & $(42.00)$ & $(42.00)$ & $(42.00)$ & $(23.00)$ & $(50.00)$ \\
\hline Female & $\begin{array}{c}49.10 \\
(49.90)\end{array}$ & $\begin{array}{c}49.80 \\
(50.00)\end{array}$ & $\begin{array}{c}35.30 \\
(47.80)\end{array}$ & $\begin{array}{c}12.40 \\
(33.00)\end{array}$ & $\begin{array}{c}68.90 \\
(46.30)\end{array}$ \\
\hline \multicolumn{6}{|l|}{ Beneficiary Status (\% households) } \\
\hline \multirow[t]{2}{*}{ BPL card } & 21.95 & 21.60 & 25.37 & 23.05 & 28.70 \\
\hline & $(41.30)$ & $(41.00)$ & $(43.50)$ & (42.10) & $(45.30)$ \\
\hline \multicolumn{6}{|l|}{ Perceptions (\% non-politicians) } \\
\hline \multirow[t]{2}{*}{ Pradhan looks after village needs } & & 38.40 & & & \\
\hline & & (48.63) & & & \\
\hline \multirow[t]{2}{*}{ Pradhan keeps election promises } & & 36.10 & & & \\
\hline & & $(48.03)$ & & & \\
\hline Village facilities better than & & 7.40 & & & \\
\hline neighboring villages & & $(26.20)$ & & & \\
\hline \multicolumn{6}{|l|}{ Village sample } \\
\hline \multirow[t]{2}{*}{ Overall GP activism } & 0.14 & & & & \\
\hline & $(0.61)$ & & & & \\
\hline \multirow[t]{2}{*}{ Village population } & 1524.80 & & & & \\
\hline & (1339.50) & & & & \\
\hline \multirow[t]{2}{*}{ Power } & 0.39 & & & & \\
\hline & $(0.35)$ & & & & \\
\hline \multirow[t]{2}{*}{ Pradhan's Village } & 38.31 & & & & \\
\hline & (48.66) & & & & \\
\hline \multirow[t]{2}{*}{ Pradhan reserved } & 54.40 & & & & \\
\hline & (49.85) & & & & \\
\hline \multirow[t]{2}{*}{ Indirect elections } & 58.77 & & & & \\
\hline & $(49.20)$ & & & & \\
\hline
\end{tabular}

Notes:

1. Years of education refer to respondent's years of education. Land owned is the acres of land owned by respondent's household. Family political history=1 if any household member has held a political position. SC/ST=1 if the respondent is a scheduled caste or scheduled tribe and female $=1$ if the respondent is a female. BPL card is a dummy=1 if household has a BPL card.

2. Each perception variable $=1$ if the respondent who agrees with statement and zero otherwise.

3. Overall GP activism is the average standardized public good provision, where we average across the following categories: roads, transport, electricity, water, sanitation, irrigation, education and health. Pradhan reserved=1 if the position of the Pradhan is reserved for women or SC/ST. Indirect elections=1 if Pradhan elections are indirect. Pradhan's village=1 if the Pradhan lives in that village. Power measures the propensity for a village to belong to all the possible voter coalitions which contain more than half the voter population in the GP. 
Table 2: Selection of Politicians

\begin{tabular}{|c|c|c|c|c|c|c|}
\hline \multirow[t]{2}{*}{ Dependent variable } & \multicolumn{3}{|c|}{ Politician } & \multicolumn{3}{|c|}{ Pradhan } \\
\hline & $(1)$ & $(2)$ & (3) & (4) & (5) & $(6)$ \\
\hline \multirow[t]{2}{*}{ Female } & 0.000 & -0.021 & 0.022 & 0.149 & -0.076 & 0.252 \\
\hline & $(0.006)$ & $(0.004)$ & $(0.004)$ & $(0.066)$ & $(0.060)$ & $(0.060)$ \\
\hline \multirow[t]{2}{*}{ SC/ST } & 0.033 & -0.006 & 0.041 & 0.133 & -0.022 & 0.175 \\
\hline & $(0.009)$ & $(0.006)$ & $(0.007)$ & $(0.081)$ & $(0.059)$ & $(0.078)$ \\
\hline \multirow[t]{2}{*}{ Education } & 0.008 & 0.005 & 0.003 & 0.020 & 0.019 & 0.006 \\
\hline & $(0.001)$ & $(0.001)$ & $(0.001)$ & $(0.009)$ & $(0.008)$ & $(0.008)$ \\
\hline \multirow[t]{2}{*}{ Land owned } & 0.008 & 0.007 & 0.001 & 0.003 & 0.003 & 0.001 \\
\hline & $(0.002)$ & $(0.002)$ & $(0.001)$ & $(0.005)$ & $(0.005)$ & $(0.005)$ \\
\hline Family political & 0.118 & 0.072 & 0.059 & 0.075 & 0.121 & -0.030 \\
\hline history & $(0.020)$ & $(0.018)$ & $(0.015)$ & $(0.067)$ & $(0.056)$ & $(0.066)$ \\
\hline Sample & $\begin{array}{l}\text { Villagers and } \\
\text { Politicians }\end{array}$ & $\begin{array}{l}\text { Villagers and } \\
\text { Unreserved } \\
\text { Politicians }\end{array}$ & $\begin{array}{l}\text { Villagers and } \\
\text { Reserved } \\
\text { politicians }\end{array}$ & All Politicians & $\begin{array}{l}\text { Village } \\
\text { councillors and } \\
\text { Unreserved } \\
\text { Pradhans }\end{array}$ & $\begin{array}{l}\text { Village } \\
\text { councillors and } \\
\text { Reserved } \\
\text { Pradhans }\end{array}$ \\
\hline $\mathrm{N}$ & 5397 & 5453 & 5349 & 536 & 421 & 456 \\
\hline
\end{tabular}

Notes:

1. OLS regressions reported with robust standard errors, clustered by village, in parentheses. All regressions include control for respondent age and age squared. Regressions in columns (1) - (3) include village fixed effects and in columns (4)-(6) GP fixed effects.

2.The dependent variable in columns (1)-(3) regressions is a dummy=1 if the respondent is a politician, and in columns (4)-(6) regressions is a dummy=1 if the respondent is a Pradhan. The explanatory variables are as defined in notes to Table 1. 
Table 3: Selection of Pradhan village

\begin{tabular}{|c|c|c|c|c|c|c|}
\hline & $(1)$ & $(2)$ & $(3)$ & $(4)$ & $(5)$ & $(6)$ \\
\hline \multirow[t]{2}{*}{ Village population } & 0.246 & 0.192 & 0.119 & 0.261 & 0.077 & 0.042 \\
\hline & $(0.037)$ & $(0.054)$ & $(0.042)$ & $(0.097)$ & $(0.034)$ & $(0.041)$ \\
\hline \multirow[t]{2}{*}{ Village population*Indirect election } & & 0.106 & & & & \\
\hline & & $(0.072)$ & & & & \\
\hline \multirow[t]{2}{*}{ Number of wards in village } & & & 0.238 & 0.132 & 0.169 & 0.150 \\
\hline & & & $(0.070)$ & $(0.147)$ & $(0.067)$ & $(0.090)$ \\
\hline \multirow[t]{2}{*}{ GP Head quarter } & & & 0.212 & 0.174 & 0.117 & 0.139 \\
\hline & & & $(0.084)$ & $(0.149)$ & $(0.092)$ & (0.091) \\
\hline \multirow[t]{2}{*}{ Fraction GP population in village } & & & & & 0.628 & \\
\hline & & & & & $(0.113)$ & \\
\hline \multirow[t]{2}{*}{ Power } & & & & & & 0.386 \\
\hline & & & & & & $(0.135)$ \\
\hline Fixed effect & Block & Block & Block & GP & Block & Block \\
\hline $\mathrm{N}$ & 394 & 394 & 389 & 389 & 368 & 389 \\
\hline
\end{tabular}


Table 4: Targeting of BPL cards

\begin{tabular}{lcccc}
\hline \hline \multirow{2}{*}{ SC/ST } & \multicolumn{4}{c}{ Dependent variable: Household has BPL card } \\
\cline { 2 - 5 } & 0.162 & 0.159 & 0.163 & 0.138 \\
\cline { 2 - 5 } Landless & $(0.019)$ & $(0.019)$ & $(0.019)$ & $(0.021)$ \\
& 0.077 & 0.080 & 0.081 & 0.075 \\
Landownership & $(0.016)$ & $(0.016)$ & $(0.015)$ & $(0.016)$ \\
& -0.002 & -0.002 & -0.003 & -0.003 \\
Education & $(0.001)$ & $(0.001)$ & $(0.001)$ & $(0.001)$ \\
& -0.006 & -0.006 & -0.006 & -0.005 \\
Family political & $(0.001)$ & $(0.001)$ & $(0.001)$ & $(0.002)$ \\
history & -0.009 & -0.018 & -0.019 & -0.022 \\
Politician & $(0.020)$ & $(0.020)$ & $(0.020)$ & $(0.020)$ \\
& & 0.078 & 0.315 & 0.309 \\
Reserved politician & & $(0.033)$ & $(0.084)$ & $(0.079)$ \\
& & & -0.185 & -0.176 \\
Pradhan & & & $(0.064)$ & $(0.059)$ \\
Politician*years of education & & & -0.070 & -0.061 \\
Pradhan's village & & & $(0.064)$ & $(0.063)$ \\
\hline \hline N & & & -0.016 & -0.017 \\
& & & $(0.007)$ & $(0.006)$ \\
& & & -0.015 \\
& & & & $(0.018)$ \\
& & & 539797 \\
\hline
\end{tabular}

Notes

1. OLS regressions with standard errors clustered by village in parenthesis. All regressions also include controls for respondent age and age squared. Regressions in columns (1)-(3) include village fixed effects and regression in column (4) block fixed effects.

2. The dependent variable is a dummy variable $=1$ if the household has a BPL card. The explanatory variables are as defined in Notes to Table 1. 
Table 5: The Determinants of Targeting

\begin{tabular}{|c|c|c|c|c|}
\hline \multirow[t]{3}{*}{ Characteristic } & \multicolumn{3}{|c|}{ Pradhan } & \multirow[b]{2}{*}{$\begin{array}{c}\text { Pradhans } \\
\text { village }\end{array}$} \\
\hline & $\underline{\text { BPL card }}$ & Education & Reserved & \\
\hline & $(1)$ & $(2)$ & $(3)$ & $(4)$ \\
\hline \multirow[t]{2}{*}{$\mathrm{SC} / \mathrm{ST}$} & 0.143 & 0.075 & 0.110 & 0.154 \\
\hline & $(0.028)$ & $(0.046)$ & $(0.028)$ & $(0.025)$ \\
\hline \multirow[t]{2}{*}{ SC/ST*Characteristic } & 0.059 & 0.009 & 0.088 & 0.009 \\
\hline & $(0.064)$ & $(0.005)$ & $(0.038)$ & $(0.038)$ \\
\hline \multirow[t]{2}{*}{ Landless } & 0.089 & 0.002 & 0.097 & 0.094 \\
\hline & $(0.019)$ & $(0.040)$ & $(0.021)$ & $(0.022)$ \\
\hline \multirow[t]{2}{*}{ Landless*Characteristic } & -0.084 & 0.008 & -0.032 & -0.033 \\
\hline & $(0.047)$ & $(0.004)$ & $(0.030)$ & $(0.030)$ \\
\hline $\mathrm{N}$ & 5104 & 5104 & 5397 & 5397 \\
\hline
\end{tabular}

Notes:

1. OLS regressions reported with robust standard errors clustered by GP in parentheses. All regressions include village fixed effect.

2. Regressions include the individual controls included in regression in column (1) Table 4. All regressions exclude the Pradhan 
Table 6a: Political power and Public good activism

\begin{tabular}{lccccc}
\hline \hline & \multicolumn{5}{c}{ Overall activism } \\
\cline { 2 - 6 } Pradhan Village & $(1)$ & $(2)$ & $(3)$ & $(4)$ & $(5)$ \\
\cline { 2 - 6 } & 0.206 & 0.115 & 0.130 & 0.123 \\
Village population & $(0.048)$ & $(0.050)$ & $(0.047)$ & $(0.051)$ & \\
& & 0.081 & 0.078 & 0.094 & 0.085 \\
Number of wards & & $(0.053)$ & $(0.049)$ & $(0.049)$ & $(0.048)$ \\
in village & & 0.104 & 0.108 & 0.098 & 0.120 \\
GP Headquarter & & $(0.085)$ & $(0.064)$ & $(0.079)$ & $(0.067)$ \\
& & -0.0042 & 0.074 & 0.076 & 0.095 \\
Power & & $(0.077)$ & $(0.065)$ & $(0.071)$ & $(0.066)$ \\
& & & 0.0004 & -0.016 & 0.051 \\
Test: Population+Number wards+ & & & $(0.100)$ & $(0.104)$ & $(0.100)$ \\
GP Headquarter & & 0.061 & 0.087 & 0.089 & 0.100 \\
Fixed effect & & $(0.033)$ & $(0.032)$ & $(0.036)$ & $(0.033)$ \\
$\mathrm{N}$ & Block & GP & Block & Block & Block \\
\hline \hline Notes & 521 & 496 & 496 & 389 & 496 \\
\hline
\end{tabular}

Notes

1. Overall activism is the equally weighted average of the eight public good outcomes reported in Table 6b. The covariance is estimated within a SUR framework. The standard errors are clustered by GP.

2. The sample in column (4) excludes the state of Kerala.

3.Village population and the number of wards is entered in logs. 
Table 6b: Political power and Public good activism: specific public good results

\begin{tabular}{|c|c|c|c|c|c|c|c|c|}
\hline & $\begin{array}{c}\text { Roads } \\
(1)\end{array}$ & Transport & $\begin{array}{r}\text { Water } \\
\text { (3) }\end{array}$ & Electricity & Sanitation & Irrigation & Education & Health \\
\hline \multirow[t]{2}{*}{ Pradhan Village } & 0.290 & 0.183 & 0.219 & 0.038 & 0.128 & -0.010 & 0.104 & 0.108 \\
\hline & $(0.110)$ & $(0.114)$ & (0.105) & $(0.083)$ & $(0.094)$ & $(0.104)$ & $(0.096)$ & $(0.076)$ \\
\hline \multirow[t]{2}{*}{ Village population } & 0.169 & -0.062 & 0.124 & 0.064 & 0.130 & 0.095 & 0.015 & 0.106 \\
\hline & $(0.086)$ & $(0.102)$ & (0.105) & $(0.095)$ & $(0.105)$ & $(0.090)$ & $(0.086)$ & (0.069) \\
\hline Number of wards & 0.171 & 0.308 & -0.019 & 0.179 & 0.165 & -0.018 & -0.005 & 0.069 \\
\hline in village & $(0.114)$ & (0.143) & $(0.121)$ & $(0.142)$ & $(0.168)$ & (0.099) & $(0.144)$ & (0.085) \\
\hline \multirow[t]{2}{*}{ GP Headquarter } & 0.251 & 0.179 & 0.009 & 0.274 & -0.003 & -0.014 & 0.052 & -0.155 \\
\hline & $(0.155)$ & $(0.144)$ & (0.154) & (0.133) & $(0.151)$ & $(0.142)$ & $(0.135)$ & (0.117) \\
\hline \multirow[t]{2}{*}{ Power } & -0.221 & -0.122 & -0.112 & 0.003 & 0.127 & -0.155 & 0.265 & 0.179 \\
\hline & $(0.196)$ & $(0.257)$ & $(0.223)$ & $(0.176)$ & $(0.247)$ & $(0.207)$ & (0.183) & (0.151) \\
\hline $\mathrm{N}$ & 496 & 496 & 496 & 496 & 496 & 496 & 496 & 496 \\
\hline
\end{tabular}

1. We use SUR estimation to obtain the covariance matrix. The standard errors are clustered by GP. All regressions include block fixed effects

2. Village population and number of wards enter in logs. 
Table 7: Other Influences on Public good activism

\begin{tabular}{|c|c|c|c|c|}
\hline & \multicolumn{4}{|c|}{ Dependent variable: Overall public good activism } \\
\hline & \multicolumn{3}{|c|}{ Pradhan } & \multirow[b]{2}{*}{$\begin{array}{l}\text { Indirect } \\
\text { election }\end{array}$} \\
\hline \multirow[t]{2}{*}{ Characteristic } & BPL card & $\begin{array}{c}\text { Years of } \\
\text { education }\end{array}$ & Reservation & \\
\hline & $(1)$ & $(2)$ & $(3)$ & (4) \\
\hline \multirow[t]{2}{*}{ Pradhan Village } & 0.134 & 0.180 & 0.161 & 0.098 \\
\hline & $(0.057)$ & $(0.095)$ & $(0.061)$ & $(0.062)$ \\
\hline \multirow[t]{2}{*}{ Characteristic } & 0.042 & 0.002 & 0.077 & \\
\hline & $(0.070)$ & $(0.007)$ & $(0.064)$ & \\
\hline \multirow[t]{2}{*}{ Pradhan Village*Characteristic } & 0.001 & -0.006 & -0.059 & 0.055 \\
\hline & $(0.098)$ & $(0.011)$ & $(0.091)$ & $(0.090)$ \\
\hline $\mathrm{N}$ & 472 & 472 & 496 & 496 \\
\hline
\end{tabular}

Notes

1. Regressions are estimated with block fixed effects with standard errors clustered by GP. The dependent variable is defined in the notes to Table 6a, and the covariance is estimated in a SUR framework.

2. All regressions include the set of explanatory variables listed in column (4) regression in Table 6a. 
Table 8: Villager Political Involvement and Pradhan's Village

\begin{tabular}{|c|c|c|c|c|c|c|}
\hline & $\begin{array}{c}\text { Reads } \\
\text { newspaper }\end{array}$ & $\begin{array}{l}\text { Affiliated } \\
\text { with Party }\end{array}$ & $\begin{array}{l}\text { Attend } \\
\text { Gram } \\
\text { Sabha } \\
\end{array}$ & $\begin{array}{c}\text { Know } \\
\text { name of } \\
\text { Legislator }\end{array}$ & $\begin{array}{c}\text { Know } \\
\text { name of } \\
\text { Pradhan }\end{array}$ & $\begin{array}{c}\text { Seen } \\
\text { Pradhan }\end{array}$ \\
\hline & $(1)$ & $(2)$ & $(3)$ & $(4)$ & (5) & (6) \\
\hline Pradhan's village & $\begin{array}{c}0.014 \\
(0.012)\end{array}$ & $\begin{array}{c}0.007 \\
(0.013)\end{array}$ & $\begin{array}{c}0.008 \\
(0.014)\end{array}$ & $\begin{array}{c}0.022 \\
(0.018)\end{array}$ & $\begin{array}{c}0.238 \\
(0.023)\end{array}$ & $\begin{array}{c}0.241 \\
(0.021)\end{array}$ \\
\hline $\mathrm{N}$ & 5133 & 5133 & 5133 & 5133 & 5133 & 5115 \\
\hline Mean & $\begin{array}{c}0.318 \\
(0.466)\end{array}$ & $\begin{array}{c}0.308 \\
(0.462)\end{array}$ & $\begin{array}{c}0.219 \\
(0.414)\end{array}$ & $\begin{array}{c}0.447 \\
(0.497)\end{array}$ & $\begin{array}{c}0.530 \\
(0.499)\end{array}$ & $\begin{array}{c}0.617 \\
(0.486)\end{array}$ \\
\hline
\end{tabular}

1. OLS regressions reported with robust standard errors clustered by GP in parentheses. All regressions include block fixed effects.

2. The sample consists of all respondents but excludes politicians. All regressions include as the set of explanatory variables listed in Column (1), Table 4. 
Table 9: Pradhan and Village Characteristics and Villager Satisfaction

\begin{tabular}{|c|c|c|c|}
\hline & Pradhan & & \\
\hline BPL card & $\begin{array}{l}\text { Years of } \\
\text { education }\end{array}$ & Reserved & $\begin{array}{l}\text { Pradhan's } \\
\text { village }\end{array}$ \\
\hline$(1)$ & $(2)$ & $(3)$ & $(4)$ \\
\hline \multicolumn{4}{|l|}{ Dep. Variable: Pradhan looks after village needs } \\
\hline-0.080 & 0.008 & -0.085 & 0.125 \\
\hline$(0.028)$ & $(0.002)$ & $(0.020)$ & $(0.021)$ \\
\hline \multicolumn{4}{|l|}{ Dep. Variable: Pradhan keeps election promises } \\
\hline-0.098 & 0.006 & -0.072 & 0.119 \\
\hline$(0.023)$ & $(0.002)$ & $(0.018)$ & $(0.020)$ \\
\hline \multicolumn{4}{|c|}{ Dep. Variable: Village facilities better than neighboring village } \\
\hline-0.002 & 0.002 & 0.017 & 0.044 \\
\hline$(0.017)$ & $(0.002)$ & $(0.018)$ & $(0.014)$ \\
\hline
\end{tabular}

Notes

1. OLS regressions reported with robust standard errors clustered by GP in parentheses. All regressions include block fixed effects.

2. Each cell reports the coefficient from a separate regression where the dependent variable is listed in the row above and the explanatory variable in the column. The sample in all regressions is the set of household respondents but excludes politician households. Regressions include as controls the set of demographic variables listed in column (1), Table 4. 
Appendix Table: Public good provision in 1961 and 1991

\begin{tabular}{|c|c|c|c|c|c|c|c|c|c|c|}
\hline & \multicolumn{5}{|c|}{1961 public good provision } & \multicolumn{5}{|c|}{1991 public good provision } \\
\hline & $\begin{array}{c}\text { Overall } \\
\text { provision }\end{array}$ & $\begin{array}{c}\text { Primary } \\
\text { school } \\
\text { present }\end{array}$ & $\begin{array}{c}\text { Medical } \\
\text { facility } \\
\text { present }\end{array}$ & $\begin{array}{c}\text { Access road } \\
\text { present }\end{array}$ & $\begin{array}{l}\text { Village has } \\
\text { electricity }\end{array}$ & $\begin{array}{c}\text { Overall } \\
\text { provision }\end{array}$ & $\begin{array}{c}\text { Primary } \\
\text { school } \\
\text { present }\end{array}$ & $\begin{array}{c}\text { Primary } \\
\text { health center/ } \\
\text { dispensary } \\
\text { present }\end{array}$ & $\begin{array}{c}\text { Metalled } \\
\text { access road }\end{array}$ & $\begin{array}{c}\text { Village has } \\
\text { power }\end{array}$ \\
\hline & $(1)$ & $(2)$ & $(3)$ & $(4)$ & (5) & $(6)$ & $(7)$ & $(8)$ & $(9)$ & $(10)$ \\
\hline Pradhan's village & $\begin{array}{l}-0.007 \\
(0.012)\end{array}$ & $\begin{array}{c}0.028 \\
(0.039)\end{array}$ & $\begin{array}{l}-0.029 \\
(0.026)\end{array}$ & $\begin{array}{l}-0.015 \\
(0.012)\end{array}$ & $\begin{array}{l}-0.012 \\
(0.025)\end{array}$ & $\begin{array}{c}0.029 \\
(0.036)\end{array}$ & $\begin{array}{c}0.058 \\
(0.076)\end{array}$ & $\begin{array}{l}-0.064 \\
(0.070)\end{array}$ & $\begin{array}{c}0.126 \\
(0.080)\end{array}$ & $\begin{array}{l}-0.002 \\
(0.034)\end{array}$ \\
\hline Village population & $\begin{array}{c}0.072 \\
(0.020)\end{array}$ & $\begin{array}{c}0.040 \\
(0.065)\end{array}$ & $\begin{array}{c}0.130 \\
(0.052)\end{array}$ & $\begin{array}{c}0.030 \\
(0.019)\end{array}$ & $\begin{array}{c}0.088 \\
(0.044)\end{array}$ & $\begin{array}{c}0.167 \\
(0.106)\end{array}$ & $\begin{array}{c}0.221 \\
(0.200)\end{array}$ & $\begin{array}{c}0.260 \\
(0.057)\end{array}$ & $\begin{array}{c}0.157 \\
(0.098)\end{array}$ & $\begin{array}{c}0.032 \\
(0.183)\end{array}$ \\
\hline $\begin{array}{l}\text { Number of wards } \\
\text { in village }\end{array}$ & $\begin{array}{c}0.009 \\
(0.005)\end{array}$ & $\begin{array}{l}-0.003 \\
(0.015)\end{array}$ & $\begin{array}{c}0.035 \\
(0.011)\end{array}$ & $\begin{array}{l}-0.002 \\
(0.002)\end{array}$ & $\begin{array}{c}0.005 \\
(0.013)\end{array}$ & $\begin{array}{l}-0.004 \\
(0.029)\end{array}$ & $\begin{array}{l}-0.034 \\
(0.049)\end{array}$ & $\begin{array}{c}0.061 \\
(0.024)\end{array}$ & $\begin{array}{c}0.023 \\
(0.021)\end{array}$ & $\begin{array}{l}-0.068 \\
(0.052)\end{array}$ \\
\hline GP Headquarter & $\begin{array}{l}-0.013 \\
(0.019)\end{array}$ & $\begin{array}{l}-0.054 \\
(0.061)\end{array}$ & $\begin{array}{l}-0.012 \\
(0.047)\end{array}$ & $\begin{array}{c}0.027 \\
(0.025)\end{array}$ & $\begin{array}{l}-0.014 \\
(0.043)\end{array}$ & $\begin{array}{l}-0.004 \\
(0.080)\end{array}$ & $\begin{array}{l}-0.154 \\
(0.157)\end{array}$ & $\begin{array}{c}0.111 \\
(0.105)\end{array}$ & $\begin{array}{c}0.009 \\
(0.113)\end{array}$ & $\begin{array}{c}0.018 \\
(0.113)\end{array}$ \\
\hline Power & $\begin{array}{l}-0.032 \\
(0.029)\end{array}$ & $\begin{array}{l}-0.016 \\
(0.099)\end{array}$ & $\begin{array}{l}-0.106 \\
(0.082)\end{array}$ & $\begin{array}{l}-0.055 \\
(0.030)\end{array}$ & $\begin{array}{c}0.049 \\
(0.055)\end{array}$ & $\begin{array}{c}0.147 \\
(0.141)\end{array}$ & $\begin{array}{c}0.195 \\
(0.285)\end{array}$ & $\begin{array}{c}0.160 \\
(0.134)\end{array}$ & $\begin{array}{c}0.130 \\
(0.210)\end{array}$ & $\begin{array}{c}0.101 \\
(0.248)\end{array}$ \\
\hline $\mathrm{N}$ & 446 & 446 & 446 & 446 & 446 & 496 & 496 & 496 & 496 & 496 \\
\hline
\end{tabular}

Notes

1. All regressions include block fixed effects and standard errors clustered by GP are in parentheses. The Overall provision variable is the equally weighted average of the four public good outcomes. The covariance matrix is estimated within a SUR framework 